\title{
Stimulation of IgM Production in HB4C5 Cell Line and Mouse Splenocytes by Egg Yolk Extract from the Egg of Indonesian Native Chicken
}

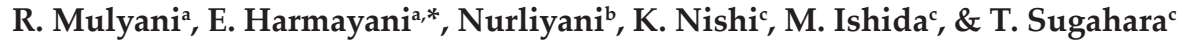 \\ ${ }^{a}$ Department of Food and Agricultural Product Technology, Faculty of Agricultural Technology, Universitas Gadjah Mada \\ Jalan Flora No. 1 Bulaksumur Yogyakarta 55281, Indonesia \\ bDepartment of Animal Products Technology, Faculty of Animal Science, Universitas Gadjah Mada \\ Jalan Fauna No. 3 Bulaksumur, Yogyakarta 55281, Indonesia \\ 'Department of Bioscience, Graduate School of Agriculture, Ehime University, Ehime, 790-8566, Japan \\ *Corresponding author: eniharmayani@ugm.ac.id \\ (Received 09-12-2020; Revised 04-05-2021; Accepted 08-06-2021)
}

\begin{abstract}
Kampung-chicken, as a local wisdom, has always been considered superior in terms of health benefits compared to commercial chicken. Therefore, this study was designed to evaluate the immunostimulatory effects of Kampung-chicken eggs using in vitro approaches. The physical (interior and exterior quality) and chemical characteristics of Kampung-chicken eggs were firstly analyzed; the commercial chicken egg was used as a comparison. The effects of water extract of Kampung-chicken egg yolk (KEYWE) and water extract of commercial-chicken egg yolk (CEYWE) on IgM production and the expression of IgM-gene on $\mathrm{HB} 4 \mathrm{C} 5$ cells were analyzed. In addition, the stimulatory effects of both samples on IgA, IgG, and IgM production by mouse primary splenocytes were analyzed as well. To isolate the active substance, the water extract from egg yolk was partially purified by salting out using $\left(\mathrm{NH}_{4}\right)_{2} \mathrm{SO}_{4}$. Data analysis of the comparison between Kampung-chicken egg and the commercial-chicken egg was performed by $t$-test; meanwhile, the results for in vitro studies were performed by one-way ANOVA, and Tukey's multiple comparison test was used for posthoc analysis. The result showed that KEYWE increased IgM production in HB4C5 cells by 5.91 fold as compared with control. In addition, KEYWE increased IgA, IgG, and IgM productions in mouse primary splenocytes by 5.20, 2.54, and 3.1 fold, respectively. Moreover, the immunoglobulin (Ig) production-stimulating activities of KEYWE on HB4C5 cells and mouse primary splenocytes were higher than those of CEYWE. The active substance in Kampung-chicken egg yolk was precipitated at $80 \%$ saturation of $\left(\mathrm{NH}_{4}\right)_{2} \mathrm{SO}_{4}$. Altogether, it is expected that the Kampung-chicken egg has more effective immunostimulatory activity than the commercial chicken egg.
\end{abstract}

\section{Keywords: native-chicken egg yolk; immunostimulatory activity; HB4C5 cells; immunoglobulin production; mouse primary splenocytes}

\section{INTRODUCTION}

The human immune system is an interactive system that works to defend the body from the invasion of foreign pathogens and identify and eliminate tumors (Marshall et al., 2018; Gonzalez et al., 2018). The state of good health is achieved by the regulation of cellular and humoral factors performing immunoregulatory functions in the human body (Abbas et al., 2012). Unfortunately, certain conditions, such as stress, poor nutrition, and aging, significantly suppress the optimal defensive capacity of human immunity (Messay et al., 2012; Bourke et al., 2016; Frasca et al., 2012). This impaired condition of immunity makes the body more susceptible to infectious disease (Nieman \& Wentz, 2019).

Growing evidence shows that nutrients from daily food intake can improve human immune function, being superior to drugs and chemicals as immunostimulants in side effects and cost (Veldhoen \& Brucklacher-Waldert, 2012; Noh et al., 2019). For instance, lactate hydrogenase in tuna was reported to enhance the immune system through stimulating Ig production of hybridoma cells and splenocytes in vitro and in vivo (Daifuku et al., 2012). In addition, hen egg-white has lysozyme, which modulates the anti-inflammatory activity and stimulates Ig production in vitro (Sugahara et al., 2000; Tagashira et al., 2018).

Hen eggs are well-known as a source of complex nutrients that promote health function (Tagashira et al., 2018; Miranda et al., 2015). Livetin, a major watersoluble protein found in the egg yolk, significantly modulate immune function by inhibiting the production of nitric oxide (NO) and pro-inflammatory cytokines (Chalamaiah et al., 2017; Meram \& Wu, 2017). In addition, eggs are loaded with bioavailable phospholipid, which is known to have pro-and anti-inflammatory properties (Andersen, 2015). Thus, egg yolk has the potential as a functional food due to its immunostimulatory activity. 
The most popular native chicken in Indonesia, namely Kampung chicken, is raised as a free-range with small amounts to no antibiotics or other drugs and reared almost throughout Indonesia (Muladno, 2008). As local wisdom, Kampung chicken has always been considered superior in health benefits compared to commercial chicken. Although Kampung chicken is raised in a free-range and under high environmental stress, research reported that Salmonella enteritidis was not found either in the serum or the egg (Jajere et al., 2019; Ulupi et al., 2014). The other study also proved that the egg yolk of Kampung chicken has a high concentration of IgY specific to S. enteritidis. Moreover, egg yolk activates the Toll-like receptor 4 (TLR4) that has been conserved in activating the innate immune system (Ulupi et al., 2014; Ulupi et al., 2013). Not only shaping the innate immune system, but TLR4 is also critically involved in the initiation of adaptive immune responses, which leads to the signaling of B cells contributing to the antibody-mediated immunity by producing Ig (Iwasaki \& Medzhitov, 2004; Ruprecht \& Lanzavecchia, 2006; Hua \& Hou, 2013).

Despite all of these prospects, no significant data are available regarding the immunostimulatory activity of the Kampung-chicken egg. Therefore, the present study aimed to investigate the immunostimulatory effects of Kampung-chicken egg using HB4C5 cell line and primary splenocytes by comparing with commercial-chicken egg yolk. HB4C5, a human-human hybridoma cell line, is a cell line that produces monoclonal IgM, was used for the assay of stimulating activity of Ig production in this experiment.

\section{MATERIALS AND METHODS}

\section{Physical and Chemical Qualities Analysis of Egg}

Fresh-hen eggs, both Kampung-chicken $(n=45)$ and commercial-chicken eggs $(n=45)$, were commercially available and obtained from a local market (Yogyakarta, Indonesia). The exterior properties, such as egg weight, egg-shape index, egg color, egg shape, and egg density from both types of eggs, were recorded. The albumen and yolk were manually separated. Eggshell thickness was recorded with a micrometer as the mean of recordings on three different egg parts. The Haugh unit (HU) was calculated according to USDA (2000). The egg-yolk color was measured using a yolk-color fan (DSM, Roche, Basel, Switzerland). The scales of egg-yolk color ranged from 1 to 15 (pale yellow to intense orange). The chemical quality of each egg, such as moisture (\%), ash (\%), lipid (\%), and crude protein (\%), were analyzed by using proximate analysis. Kampung-chicken egg yolk and commercial-chicken egg yolks were homogenized and lyophilized.

\section{Preparation of Egg-Yolk Extract}

The preparation of egg-yolk solution was conducted by following the previous experiment with modification (Hernandez-Campoz et al., 2010). Lyophilized egg yolks from Kampung-chicken eggs and commercial-chicken eggs were firstly suspended in distilled water. Next, the $\mathrm{pH}$ of the egg-yolk suspension was adjusted to $\mathrm{pH} 5$ by using $1 \mathrm{~N} \mathrm{HCl}$ to remove lipids and stirred at $10^{\circ} \mathrm{C}$ for $24 \mathrm{~h}$. After that, the egg-yolk suspension was centrifuged at $32,300 \times g$ at $4^{\circ} \mathrm{C}$ for 20 min. Then, the supernatant was adjusted to $\mathrm{pH} 7.4$ by using $\mathrm{HCl}$ or $\mathrm{NaOH}$ and sterilized by $0.22 \mu \mathrm{m}$ filter. The sterilized samples were kept at $4^{\circ} \mathrm{C}$ and utilized as the Kampung-chicken egg-yolk water-extract (KEYWE) and commercial-chicken egg-yolk water-extract (CEYWE) for further analysis.

The ethanol extraction of egg yolk was conducted according to Su et al. (2015) method with a modification. The lyophilized egg yolk was dissolved with ethanol, and the mixture was stirred for $24 \mathrm{~h}$ at $15 \mathrm{rpm}$. The mixture was then centrifuged at $32,300 \times g$ at $4^{\circ} \mathrm{C}$ for $20 \mathrm{~min}$. The supernatant was evaporated for 20 minutes, and the ethanol-extracted fractions were dissolved into desired concentration. It was then sterilized by $0.45 \mu \mathrm{m}$ filter and kept in the refrigerator until further use.

\section{Immunostimulant Effect of Egg-Yolk Water Extract Using HB4C5 Cells}

The cell culture of HB4C5 cells was conducted using a previously described method by Sugahara et al. (2000). The human hybridoma cell line HB4C5 cells producing IgM were cultured in ERDF medium supplemented with $10 \%$ fetal bovine serum (FBS) at $37^{\circ} \mathrm{C}$ in $5 \%$ $\mathrm{CO}_{2}$.

The Ig production-stimulating activities of KEYWE and CEYWE were evaluated by measuring the amount of IgM in the culture medium of HB4C5 cells. HB4C5 cells were cultured in ERDF medium supplemented with $10 \mu \mathrm{g} / \mathrm{mL}$ of insulin, $20 \mu \mathrm{g} / \mathrm{mL}$ of transferrin, 20 $\mu \mathrm{M}$ ethanolamine, and $25 \mu \mathrm{M}$ sodium selenite (ITESERDF medium) at the concentration of $3 \times 10^{5}$ cells/well. Following the cell seeding, various concentrations of KEYWE or CEYWE and distilled water as a control were added into a 96-well culture plate. The culture plate was then incubated at $37^{\circ} \mathrm{C}$ for $6 \mathrm{~h}$. Following the incubation period, the culture medium was collected to analyze the concentration of IgM by using enzyme-linked immunosorbent assay (ELISA) as previously described by Sugahara et al. (2000).

Firstly, goat anti-human IgM antibody was added at $100 \mu \mathrm{L} /$ well as a coating to a 96-well plate and incubated overnight at $4^{\circ} \mathrm{C}$. Phosphate-buffered saline (PBS) with Tween 20 (PBS-T) was used as a washing solution into each well in three replications. After washing, PBS containing 5\% skim-milk was used as a blocking solution for $2 \mathrm{~h}$ at $37^{\circ} \mathrm{C}$. Following the blocking reaction, 50 $\mu \mathrm{L}$ of culture supernatant was added into each well for $1 \mathrm{~h}$ at $37^{\circ} \mathrm{C}$. After washing, $100 \mu \mathrm{L}$ of horseradish peroxidase (HRP)-conjugated anti-human IgM antibody diluted 2,000 times with PBS containing 5\% skim milk was added into each well as a second antibody, and it was incubated at $37^{\circ} \mathrm{C}$ for $1 \mathrm{~h}$. Then, 2,2'-azino-bis (3-ethylbenzothiazoline-6-sulfonic acid) (ABTS) dissolved in 50 $\mathrm{mM}$ citrate buffer ( $\mathrm{pH} 4.0$ ) containing $\mathrm{H}_{2} \mathrm{O}_{2}$ was added to each well at $100 \mu \mathrm{L}$. After the addition of $100 \mu \mathrm{L}$ of $1.5 \%$ oxalic acid, the absorbance was measured at 415 $\mathrm{nm}$. The assays were repeated three times. 


\section{Reverse Transcription-Polymerase Chain Reaction (RT-PCR)}

The expression of the IgM gene was evaluated by a real-time RT-PCR assay as previously described by Nishimoto et al. (2012). According to the manufacturer's instructions, the total RNA from the cell was isolated using Sepasol RNA I Super G (Nacalai Tesque, Japan). Next, the cDNA was synthesized from total RNA using an MMLV reverse transcriptase and oligo-dT primer (Promega, USA). The thermal cycling process was done at $70^{\circ} \mathrm{C}$ for $1 \mathrm{~h}$. After that, the real-time PCR mixture consisted of 2,5 $\mathrm{g}$ of a cDNA sample, $10 \mu \mathrm{M}$ forward primer, $10 \mu \mathrm{M}$ reverse primer, and thunderbird SYBR qPCR Mix (Toyobo, Japan) were mixed for $5 \mathrm{~min}$. The mixture was measured using a StepOnePlus real-time PCR System (Applied Biosystems). After that, the comparative CT method was calculated using StepOne Software v2.1 (Applied Biosystems) to evaluate the relative gene expression. The endogenous reference used for this experiment was human glyceraldehyde-3-phosphate dehydrogenase (GAPDH) with a specific primer sequence: 5'-GCACCGTCAAGGCTGAGAAC-3'(sense) and 5'-TGGTGAAGACGCCAGTGGA-3'(antisense). Meanwhile, the primer sequence for human IgM: 5'-CTCCCAAAGTGAGCGTCTTC-3' (sense) and 5' -CAGCCAGGACACCTGAATCT-3'(antisense).

\section{Immunostimulant Effect of Egg-Yolk Extract on Mouse Primary Splenocytes}

Three 5-week-old female BALB/c mice (Japan CLEA) were housed in an animal room under 12/12 $\mathrm{h}$ light/dark cycle at a temperature of $24 \pm 1^{\circ} \mathrm{C}$ fed with a pelleted basal diet, and water was available ad libitum. All animal experiments described herein were carried out under the protocol approved by the Laboratory Animal Care Committee of Ehime University (approval number: 08U2-1). The experimental mice were maintained in accordance with the Guidelines for the Care and Use of Laboratory Animals of Ehime University. The splenocytes preparation was conducted as described previously by Kumalasari et al. (2012). After one week of acclimation, the mice were sacrificed by cervical dislocation, and the spleens were taken out. The spleens were ground into a culture dish through a mesh with a pore size of $40 \mu \mathrm{m}$. The splenocytes suspension was centrifuged at 1,200 rpm for $5 \mathrm{~min}$ and hemolyzed using hemolysis buffer. After that, the splenocytes were washed with PBS and centrifuged at $190 \times g$ for $5 \mathrm{~min}$. The obtained primary splenocytes were suspended in 5\% FBS-RPMI 1640 medium and inoculated into each well of a 96-well culture plate at $5 \times 10^{5}$ cells/ well. Following the seeding of the splenocytes cell, the KEYWE or CEYWE was added into 96 well-plate, and the plate was incubated at $37^{\circ} \mathrm{C}$ for $48 \mathrm{~h}$. Production of Immunoglobulins, namely $\operatorname{Ig} \mathrm{A}, \operatorname{IgG}$, and $\operatorname{IgM}$, secreted into the culture medium was determined by ELISA as described previously (Daifuku et al., 2012). The assays were carried out in triplicate.

\section{Partial Purification of Egg-Yolk Water Extract using Ammonium Sulfate}

Partial purification of egg-yolk water extract was done by salting out using $\left(\mathrm{NH}_{4}\right)_{2} \mathrm{SO}_{4}$, according to Ko \& Ahn (2007). The sample of water extract of egg yolk was precipitated at $40 \%, 60 \%, 80 \%$, and $100 \%$ saturation of $\left(\mathrm{NH}_{4}\right)_{2} \mathrm{SO}_{4}$ at $4{ }^{\circ} \mathrm{C}$, and the pellet was dissolved in distilled water and dialyzed against $10 \mathrm{mM}$ phosphate buffer $\mathrm{pH} 7.0$ for $48 \mathrm{~h}$ to remove $\left(\mathrm{NH}_{4}\right)_{2} \mathrm{SO}_{4}$. SDS-polyacrylamide gel electrophoresis (PAGE) was performed on a $15 \%$ polyacrylamide gel. Proteins were stained with Coomassie brilliant blue.

\section{Statistical Analysis}

Comparison between Kampung egg and the commercial egg was performed by t-test using SPSS version 26. Meanwhile, the results for in vitro studies were performed by one-way ANOVA using SPSS version 26. Tukey's multiple comparison test was used for posthoc analysis. All the presented data resulted from triplicated experiments and were expressed as mean \pm standard deviation (SD).

\section{RESULTS}

\section{Physical and Chemical Quality of Egg Yolk}

The means and standard deviation of egg-quality data are presented in Table 1. The commercial-chicken egg was heavier (62.41 g) than the Kampung-chicken egg (42.30 g). Both eggs showed similar conical shapes and similar values of egg densities. However, the Kampung-chicken egg had a sharper shape than the commercial-chicken egg (egg shape indexes were 1.40 and 1.04, respectively, $\mathrm{p}<0.01)$. Commercial-chicken egg showed a thicker eggshell compared to Kampungchicken egg $(p<0.01)$. According to the interior properties, there were no differences in the yolk and albumen indices between Kampung and commercial-chicken eggs. However, Kampung-chicken egg showed a higher yolk percentage than a commercial-chicken egg $(\mathrm{p}<0.01)$. In contrast, commercial-chicken eggs showed a higher percentage in the albumen. Kampung-chicken egg had a darker color than the commercial-chicken egg (yolk colors were 10.08 and 7.42 , respectively, $\mathrm{p}<0.01$ ). However, the Haugh Unit score of the Kampung-chicken egg was significantly lower than that of the commercial-chicken egg $(\mathrm{p}<0.01)$.

According to chemical properties (Table 2), Kampung-chicken egg yolk had higher moisture and ash contents $(\mathrm{p}<0.01)$. Kampung-chicken egg had a slightly lower fat percentage than the commercial-chicken egg yolk $(p<0,01)$. In addition, Kampung-chicken egg yolk contained a higher protein percentage than the commercial-chicken egg yolk $(\mathrm{p}<0.01)$. From the physical and chemical analysis result, there were differences in physical quality, both interior and exterior qualities, and chemical qualities of Kampung-chicken egg and commercial-chicken egg. 
Table 1. Comparative egg quality of Kampung-chicken egg and commercial layer-chicken egg (Mean \pm SD)

\begin{tabular}{lrcc}
\hline Variables & \multicolumn{1}{c}{ KCE } & \multicolumn{1}{c}{ CLE } & p-Value \\
\hline Exterior & & & \\
Egg weight (g) & $42.30 \pm 2.82$ & $62.41 \pm 3.56$ & $* *$ \\
Egg shape index & $77.95 \pm 5.31$ & $79.15 \pm 3.14$ & NS \\
Egg color (score) & $1.08 \pm 0.41$ & $2.00 \pm 0.00$ & $*$ \\
Egg shape (score) & $1.40 \pm 0.61$ & $1.04 \pm 0.29$ & $* *$ \\
Egg density & $1.08 \pm 0.05$ & $1.10 \pm 0.04$ & NS \\
Shell thickness (mm) & $0.42 \pm 0.05$ & $0.58 \pm 0.05$ & $* *$ \\
Interior & & & \\
Yolk index & $39.45 \pm 5.30$ & $38.34 \pm 7.58$ & NS \\
Yolk (\%) & $31.52 \pm 3.17$ & $23.90 \pm 2.27$ & $* *$ \\
Yolk color & $10.08 \pm 0.73$ & $7.42 \pm 0.61$ & $* *$ \\
Albumen index & $6.90 \pm 2.01$ & $10.54 \pm 2.25$ & NS \\
Albumen (\%) & $51.45 \pm 3.38$ & $58.90 \pm 4.41$ & $* *$ \\
Haugh unit (score) & $74.26 \pm 9.22$ & $88.67 \pm 6.57$ & $* *$ \\
\hline
\end{tabular}

Note: $\mathrm{KCE}=$ Kampung-chicken egg; CLE $=$ commercial-layer-chicken egg; ${ }^{*}=(\mathrm{p}<0.05) ;{ }^{* *}=(\mathrm{p}<0.01) ; \mathrm{NS}=$ not significant.

\section{IgM Production by HB4C5 Cells Treated by Egg-Yolk Extract}

Both ethanol and distilled-water extracts of egg yolk increased the production of $\operatorname{IgM}$ in dosedependent manners. Nevertheless, the ethanol extracts of Kampung-chicken egg yolk and commercial-chicken egg yolk stimulated IgM production by HB4C5 cells at similar levels (Figure 1A). On the other hand, KEYWE stimulated IgM production more effectively (Figure 1B) compared to CEYWE, namely KEYWE increased IgM production 5.91 -fold at a dose of $20 \mathrm{mg} / \mathrm{mL}$. In contrast, CEYWE increased IgM production 4.70-fold at the same concentration. Therefore, KEYWE and CEYWE were used for further experiments. Interestingly, at the low-
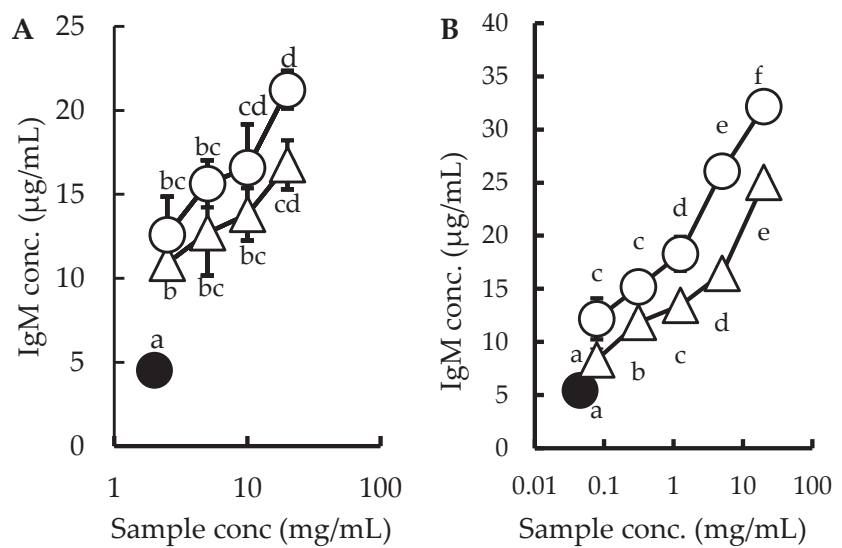

Figure 1. IgM production by HB4C5 cells supplemented by egg yolk extract, (A) Ethanol extraction, (B) Distilled water extraction. A closed circle, open circle, and open triangle represent the IgM production by $\mathrm{HB} 4 \mathrm{C} 5$ cells cultures in ITES-ERDF medium supplemented with control (ethanol and DW), Kampung-chicken eggyolk water-extract (KEYWE), and commercial-chicken egg-yolk water-extract (CEYWE), respectively. Means denoted by different letters indicate significant difference between treatments (Tukey's HSD, $\mathrm{p}<0.05$ ), $\mathrm{n}=3$.
Table 2. Comparative chemical quality egg yolk of Kampungchicken egg and commercial-chicken egg

\begin{tabular}{lrrc}
\hline Variables & \multicolumn{1}{c}{ KCE } & \multicolumn{1}{c}{ CCE } & p-Value \\
\hline Moisture (\%) & $48.22 \pm 0.05$ & $47.67 \pm 0.01$ & $* *$ \\
Ash (\%) & $2.34 \pm 0.02$ & $2.10 \pm 0.01$ & $* *$ \\
Fat $(\%)$ & $30.41 \pm 0.08$ & $30.81 \pm 0.10$ & $* *$ \\
Crude Protein (\%) & $16.71 \pm 0.01$ & $16.11 \pm 0.01$ & $* *$ \\
\hline
\end{tabular}

Note: $\mathrm{KCE}=$ Kampung-chicken egg; $\mathrm{CCE}=$ commercial-chicken egg; ${ }^{* *}=(\mathrm{p}<0.01)$.

est concentration, CEYWE did not show any activity to stimulate IgM production $(\mathrm{p}>0.05)$ compared with the control. Nevertheless, at the same lowest concentration, KEYWE significantly stimulated $\operatorname{IgM}$ production 2.4-fold.

To evaluate the mode of action of KEYWE on IgM production, the level of IgM gene expression in HB4C5 cells was evaluated by quantitative real-time RT-PCR. The data showed that both KEYWE and CEYWE increased the levels of IgM-gene expressions (Figure 3). Nonetheless, KEYWE stimulated the level of IgM gene expression more effectively in $\mathrm{HB} 4 \mathrm{C} 5$ cells compared to CEYWE.

\section{Mouse Splenocyte Treated by Water Extract of Egg Yolk}

In the next step, we evaluated the stimulating activities of KEYWE and CEYWE on Ig production by mouse primary splenocytes. The mouse primary splenocytes were supplemented with KEYWE and CEYWE and incubated for $48 \mathrm{~h}$. The level of Ig production in the culture medium was measured using ELISA.

KEYWE and CEYWE increased IgA, IgG, and IgM productions with the increased dose of treatment (Figure 4). At the highest concentration used, KEYWE and CEYWE increased $\operatorname{IgA}$ productions 5.2-folds and 2.04-folds, respectively ( $p<0.05)$. Different from KEYWE, CEYWE did not significantly increase IgA at the lowest
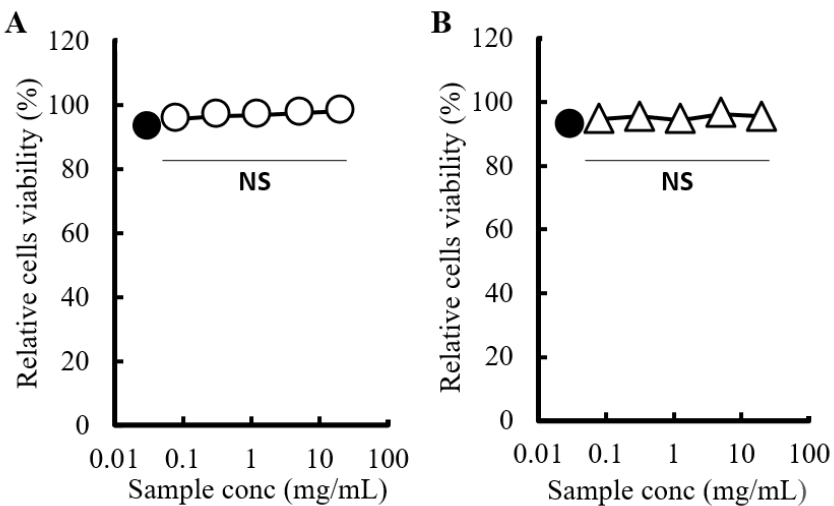

Figure 2. Cell viability of egg-yolk water extract on HB4C5 cells, (A) Relative cells viability of HB4C5 cells treated with Kampung-chicken egg-yolk water-extract (KEYWE), (B) Relative cells viability of HB4C5 cells treated with commercial-chicken egg-yolk water-extract (CEYWE). Means denoted by different letters indicate significant difference between treatments (Tukey's HSD, $p<0.05$ ). NS= Not significant. 
concentration (Figure 4). IgG productions increased significantly only at the highest concentrations of KEYWE and CEYWE. However, there was no significant difference in IgG production between the KEYWE and CEYWE. IgM production of mouse primary splenocytes was enhanced by both KEYWE and CEYWE. The results showed that KEYWE effectively increased IgM production 3.10-fold, while CEYWE increased IgM production only 2.43-fold at the highest concentration.

\section{Partial Purification of Active Substance in Water Extracts of Egg Yolk}

KEYWE and CEYWE water extract of egg yolk were then subjected to salting out by $\left(\mathrm{NH}_{4}\right)_{2} \mathrm{SO}_{4}$ precipitation to isolate the active substance, which stimulated IgM production by HB4C5 cells. Partial purification of the water extracts of egg yolk was carried out by salt-

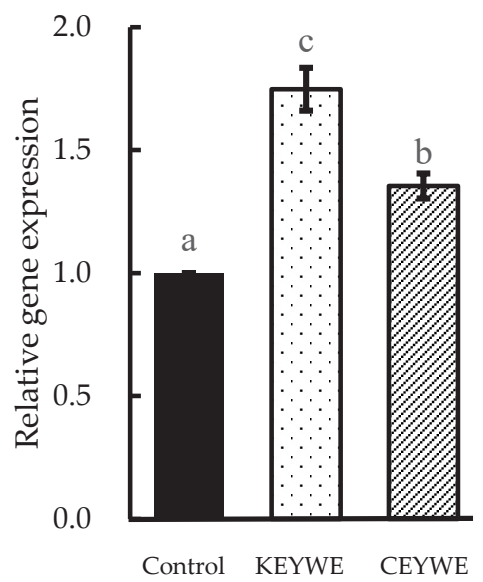

Figure 3. IgM gene expression supplemented by egg-yolk water extract. Means denoted by different letters indicate significant difference (Tukey's HSD, $\mathrm{p}<0.05$ ), $\mathrm{n}=3$; KEYWE= Kampung-chicken egg-yolk water-extract; CEYWE $=$ commercial-chicken egg-yolk water-extract. ing out with $40 \%, 60 \%, 80 \%$, and $100 \%$ saturation of $\left(\mathrm{NH}_{4}\right)_{2} \mathrm{SO}_{4}$. Precipitates at $40 \%, 60 \%$, and $80 \%$ saturation of $\left(\mathrm{NH}_{4}\right)_{2} \mathrm{SO}_{4}$ from both samples of KEYWE and CEYWE had the stimulating effect on IgM production by HB4C5 cells (Figure 5). However, the specific activities of $80 \%$ saturated fractions of KEYWE and CEYWE were the highest among those of intact KEYWE and CEYWE $(p<0.05)$. Moreover, the precipitate of KEYWE at $80 \%$ saturated $\left(\mathrm{NH}_{4}\right)_{2} \mathrm{SO}_{4}$ stimulated the highest increased in IgM production compared with the precipitate of CEYWE $(p<0.05)$. Figure 6 shows the SDS-PAGE analysis of partially purified water extract of egg yolk by salting out. The water extracts of egg yolk from Kampungchicken egg and commercial-chicken egg contained a complex protein with molecular weights ranged from 20 to $250 \mathrm{kDa}$. Partial purification by salting out created a slightly different protein composition compared to that of the crude egg-yolk water-soluble fraction. The active substance, precipitate at $80 \%$ saturated $\left(\mathrm{NH}_{4}\right)_{2} \mathrm{SO}_{4}$ was composed of proteins with molecular weight from 37 to $150 \mathrm{kDa}$

\section{DISCUSSION}

Based on our review, this study is the first to evaluate the immunostimulatory activity of egg-yolk extract using HB4C5 cells and mouse primary splenocytes, more specifically on Kampung-chicken eggs. Therefore, to obtain a comprehensive overview of Kampungchicken egg, physical and chemical analysis was essential to be done.

According to physical quality analysis, the Kampung-chicken egg was categorized as small, while the commercial-chicken egg was categorized as large (Table 2). This categorization was based on the egg categorization by the American Association, which divide the egg into small (42-49 g), medium (49-56), large (56-65 g), extra-large $(65-70 \mathrm{~g})$, and jumbo $(>70$ g) (USDA, 2000). Interestingly, the small size of the
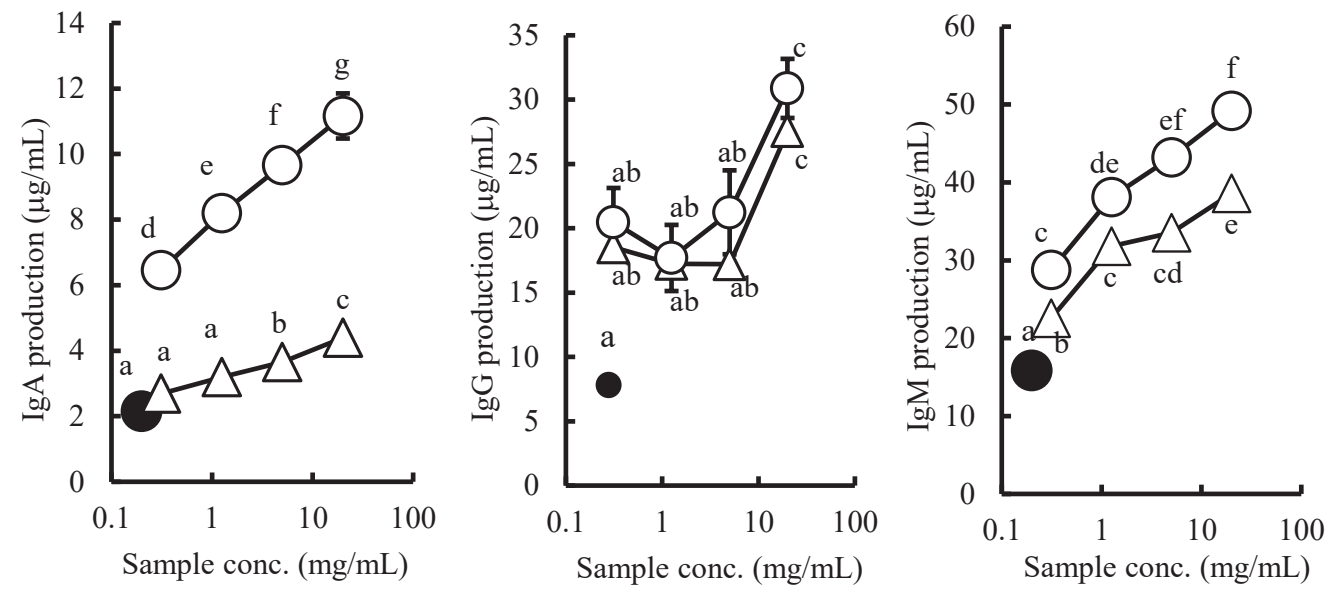

Figure 4. Mouse primary splenocytes supplemented by egg-yolk water extract. A closed circle, open circle, and open triangle represent the Ig production by mouse primary splenocytes cultures supplemented with distilled water as a control, Kampung-chicken egg-yolk water-extract (KEYWE), and commercial-chicken egg-yolk water-extract (CEYWE), respectively. Means denoted by different letters indicate significant difference (Tukey's HSD, $\mathrm{p}<0.05), \mathrm{n}=3$. 


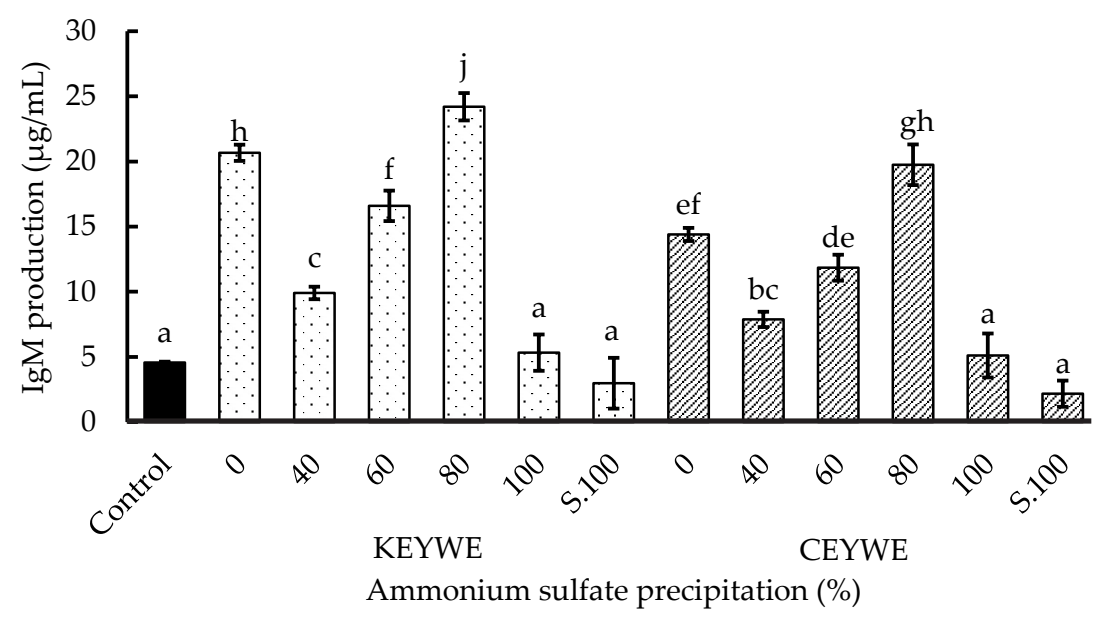

Figure 5. The $\left(\mathrm{NH}_{4}\right)_{2} \mathrm{SO}_{4}$ precipitation of egg-yolk water extract on the production of IgM from HB4C5 cells, S.100= Supernatant, obtained from $100 \%$ ammonium sulfate precipitation. Means denoted by different letters indicate significant difference (Tukey's HSD, $\mathrm{p}<0.05$ ), $\mathrm{n}=3$; KEYWE= Kampung-chicken egg-yolk water-extract; CEYWE $=$ commercial-chicken egg-yolk water-extract.

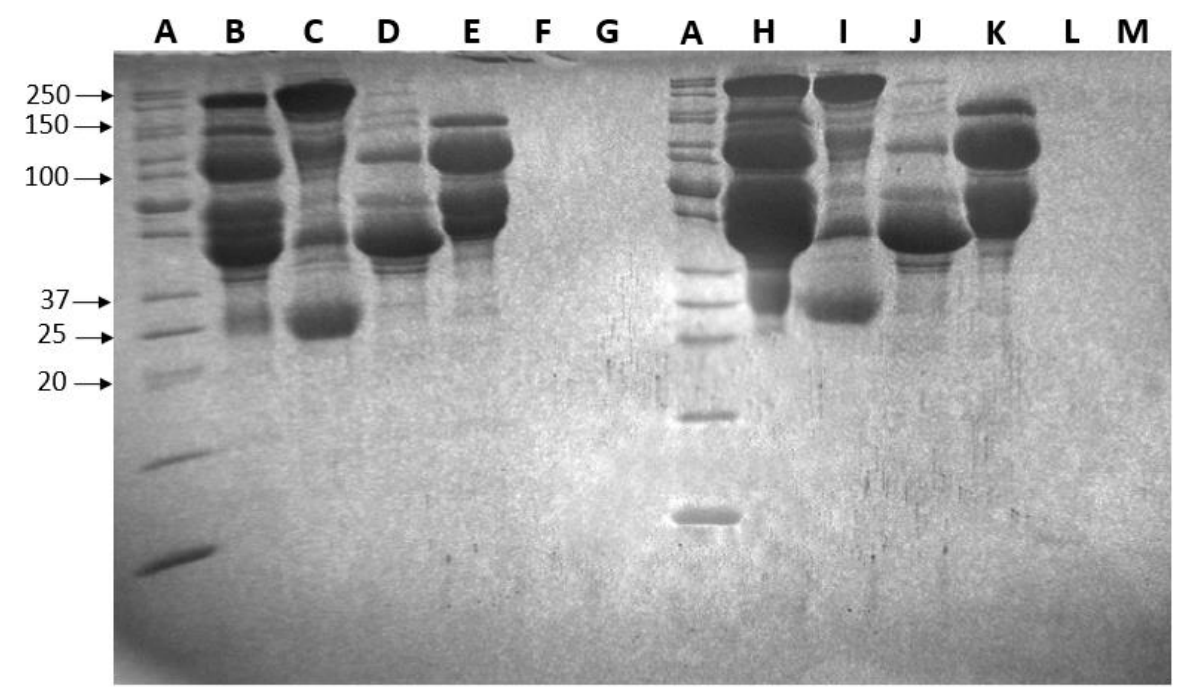

Figure 6. SDS-PAGE analysis of partially purified egg-yolk water extracts by $\left(\mathrm{NH}_{4}\right)_{2} \mathrm{SO}_{4}$ precipitation. (A) marker, (B) CEYWE with $0 \%\left(\mathrm{NH}_{4}\right)_{2} \mathrm{SO}_{4},(\mathrm{C})$ CEYWE with $40 \%\left(\mathrm{NH}_{4}\right)_{2} \mathrm{SO}_{4}$, (D) CEYWE with $60 \%\left(\mathrm{NH}_{4}\right)_{2} \mathrm{SO}_{4}$, (E) CEYWE with $80 \%\left(\mathrm{NH}_{4}\right)_{2} \mathrm{SO}_{4},(\mathrm{~F})$ CEYWE with $100 \%\left(\mathrm{NH}_{4}\right)_{2} \mathrm{SO}_{4},(\mathrm{G})$ Supernatant of CEYWE with $100 \%\left(\mathrm{NH}_{4}\right)_{2} \mathrm{SO}_{4}$, (H) KEYWE with $0 \%\left(\mathrm{NH}_{4}\right)_{2} \mathrm{SO}_{4}$, (I) KEYWE with $40 \%\left(\mathrm{NH}_{4}\right)_{2} \mathrm{SO}_{4}$, (J) KEYWE with $60 \%\left(\mathrm{NH}_{4}\right)_{2} \mathrm{SO}_{4},(\mathrm{~K})$ KEYWE with $80 \%\left(\mathrm{NH}_{4}\right)_{2} \mathrm{SO}_{4}$, (L) KEYWE with $100 \%\left(\mathrm{NH}_{4}\right)_{2} \mathrm{SO}_{4}$, (M) Supernatant of KEYWE with 100\% $\left(\mathrm{NH}_{4}\right)_{2} \mathrm{SO}_{4}$. KEYWE= Kampung-chicken egg-yolk water-extract; CEYWE= commercial-chicken egg-yolk water-extract.

Kampung-chicken egg shows a higher percentage of yolk than the commercial-chicken egg. In contrast, the commercial-chicken egg was enriched with a higher albumen percentage than the Kampung-chicken egg. This result was in accordance with a previous study that shows native chickens tend to have a higher amount of yolk (Lordelo et al., 2019). This difference is attributed to the hen's genotype, with native breeds having a higher yolk percentage. According to USDA (2000), both eggs are categorized have AA quality $(>71)$, indicating that they had a good internal quality. Nevertheless, this study shows that Kampung-chicken egg has lower HU than the commercial-chicken egg. This result is in accordance with the previous report showing that egg weight influenced the interior quality of the egg (Shi et al., 2009; Jones, 2012; Cahyadi et al., 2015). The breed of chicken and genetic differences were also found to influence the interior quality, such as HU value in eggs (Hanusova et al., 2015; Sokolwicz et al., 2018). Moreover, previous reports on various studies of native eggs also described lower weight and lower HU (Rehman et al., 2016; Edmew et al., 2018; Wambui et al., 2018). In addition to that, Wulandari et al. (2015) also found out that Kampung-chicken egg has lower HU than the commercial-chicken egg.

Kampung-chicken egg yolk had a darker color compared to commercial-chicken egg yolk. The color of the egg yolk is influenced by the feeding and access to free-range vegetation. As Kampung chickens have access to abundant natural carotenoids in 
vegetation, their yolk color showed intensely darker than the commercial-chicken egg in which the feed is controlled (Gałazka-Czarnecka et al., 2019; Lordelo et al., 2017). Previous reports showed three main differences between Kampung chicken and commercial chicken: strain, feed (small amount of antibiotic or no antibiotic or drugs at all), and rearing system (Hidayat \& Asmarasari, 2015). The different vegetation and access to various types of feed explained the difference in protein and lipid content of the Kampung-chicken egg (Table 2). This result corresponds to the previous result showing that Kampung-chicken egg has significantly higher protein and lower fat than a commercial-chicken egg (Wei et al., 2019).

After identifying the differences in both physical and chemical properties in Kampung-chicken egg and commercial-chicken egg, the samples were extracted using ethanol and distilled water to screen the activity of Kampung-chicken egg yolk on Ig-producing cells. Samples were added to the culture medium of HB4C5 cells at various concentrations and cultured for $6 \mathrm{~h}$. Following the cultivation, the amount of $\operatorname{IgM}$ in the culture medium was measured by ELISA.

According to Figure 1, both extracts of egg yolk in ethanol and water stimulated IgM production of HB4C5 cells. However, the activity of water extracts was stronger than that of ethanol extracts. Ethanol extraction was conducted to obtain phospholipid from the egg yolk. As previously reported by Anderson (2015), egg-derived phospholipid had immune-enhancing activity in vitro and in vivo study. Since water-soluble content can effectively stimulate IgM production by HB4C5 cells than ethanol-soluble content in egg yolk, we decided to conduct distilled water extraction for sample preparation for further experiments.

According to Figure 1B, KEYWE was more effective in stimulating $\operatorname{IgM}$ production than CEYWE $(\mathrm{p}<0.05)$, and neither of the samples showed cytotoxicity to HB4C5 cells up to $20 \mathrm{mg} / \mathrm{mL}$ (Figure 2). In addition, the quantitative real-time RT-PCR result showed that KEYWE was more effectively up-regulated IgM gene expression than CEYWE at the same sample concentration. As a result, it was suggested that KEYWE stimulates IgM production of HB4C5 cells by elevating the level of IgM gene expression.

Next, our result demonstrated that KEYWE increased $\operatorname{IgA}, \operatorname{IgG}$, and $\operatorname{Ig} M$ productions of mouse primary splenocytes in vitro. A previous study reported that the increased Ig production is a good indicator of B cell (plasma cell) activity. Therefore, the activated B cells will differentiate into plasma cells producing Igs (Goto et al., 2010; Sarker \& Gohda, 2013). Therefore, the present study demonstrated that KEYWE activated B cells and promoted the differentiation of B cells to antibodysecreting plasma. Antibodies provide the ability to neutralize toxins and generate long-term protection from the invasion of microorganisms into the host cells. In addition, the antibody-antigen complexes will activate the complement cascade of the immune system (Actor, 2019; Cyster \& Allen, 2019).

A previous study has reported that water-soluble fractions from egg yolk stimulated immune response through enhancing B cell activity in mice (Lee et al., 2013). This study found that water extract of egg yolk, especially from Kampung chicken, strongly activates Ig production of HB4C5 cells and mouse primary splenocytes. In addition, the active substance was successfully isolated by salting out at $80 \%$ saturation of $\left(\mathrm{NH}_{4}\right)_{2} \mathrm{SO}_{4}$. According to SDS-PAGE analysis (Figure 6), many bands were observed at the $80 \%$-saturated fraction. This indicates that it might be a complex protein with a molecular weight ranging from 37 to $150 \mathrm{kDa}$. We assume that KEYWE contains mostly water-soluble fractions such as livetin, IgY, unknown peptides, amino acids. A previous study conducted by Meram \& Wu (2017) also showed that livetin, whose molecular weight ranged from 37 to $104 \mathrm{kDa}$, has the ability to enhance immunity through in vitro study. However, further studies in vitro and in vivo are needed to identify the active substance in KEYWE and evaluate the mode of action.

\section{CONCLUSION}

Based on the results of this study, it is concluded that Kampung-chicken egg and commercial-chicken egg have different physical and chemical characteristics. Water-soluble fraction of egg yolk from Kampung chicken had the immunostimulant activity through enhancing Ig production of human hybridoma cell line HB4C5 cells and mouse primary splenocytes more effectively than that from a commercial-chicken egg. The active substance in Kampung-chicken egg yolk was successfully precipitated at $80 \%$ saturated $\left(\mathrm{NH}_{4}\right)_{2} \mathrm{SO}_{4}$. With all the experimental results, it is expected that the Kampung-chicken egg has more effective immunostimulatory activity than a commercial-chicken egg.

\section{CONFLICT OF INTEREST}

We certify that there is no conflict of interest with any financial, personal, or other relationships with other people or organizations related to the material discussed in the manuscript.

\section{ACKNOWLEDGEMENT}

This research would not have been possible without JASSO Scholarship through SUIJI-JP-MS program for providing the opportunity and financial supports, enabling us to do this research. Animal experiments were accomplished at the Division of Genetic Research of the Advanced Research Support Center (ADRES), Ehime University.

\section{REFERENCES}

Abbas, A. K., Andrew H. Litchman, \& S. Pillai. 2012. Cellular and Molecular Immunology. $7^{\text {th }}$ Ed. Elsevier Saunders, Philadelphia.

Actor, J. K. 2019. The B Lymphocyte: Antibodies and How They Function. In Introductory Immunology, $2^{\text {nd }} \mathrm{Ed} . \mathrm{p}$. 31-44. Elsevier Inc., Philadelphia. https://doi.org/10.1016/ B978-0-12-816572-0.00003-6 
Andersen, C. J. 2015. Bioactive egg components and inflammation. Nutrients 7: 7889-7913. https://doi:10.3390/nu7095372

Bourke, C. D., J. A. Berkley, \& A. J. Prendergast. 2016. Immune dysfunction as a cause and consequence of malnutrition. Trends Immunol. 37:386-298. https://doi.org/10.1016/j. it.2016.04.003

Cahyadi, M., R. Fauzy, \& R. Dewanti. 2015. Egg production traits and egg quality characteristic in black and brown plumage color lines of Japanese quail. Poult. Sci. J. 7:179-184.

Chalamaiah, M., Y. Esparza, F. Temelli, \& J. Wu. 2017. Physicochemical and functional properties of livetins fraction from hen egg yolk. Food Biosci. 18:38-45. https://doi. org/10.1016/j.fbio.2017.04.002

Cyster, J. G. \& C. D. C. Allen. 2019. B cell response: cell interaction dynamics and decisions. Cell 177:524-540. https://doi. org/10.1016/j.cell.2019.03.016

Daifuku, M., K. Nishi, T. Okamoto, H. Nakano, S. Nishimoto, \& T. Sugahara. 2012. Immunostimulatory effects of water extract from bulbus arteriosus in tuna in vitro. J. Funct. Foods. 4:263-70. https://doi.org/10.1016/j.jff.2011.12.002

Edmew, E., A. Melesse, M. Beyan, \& M. Taye. 2018. Assesing the performance, egg quality, and carcass of indigenous chickens reared under traditional management system. Int. J. Res. Stud. Agric. Sci. 4:27-35.

Frasca, D., A. Diaz, M. Romero, A. M. Landin, \& B. B. Blomberg. 2012. Age effects on B cells and humoral immunity in humans. Ageing Res. Rev. 10:330-335. https://doi. org/10.1016/j.arr.2010.08.004

Gałazka-Czarnecka, I., E. Korzeniewska, A. Czarnecki, M.Sójka, P. Kiełbasa, \& T. Drózdź. 2019. evaluation of quality of eggs from hens kept in caged and free-range systems using traditional methods and ultra-weak luminescence. Appl. Sci. 9:1-12. https://doi.org/10.3390/app9122430

Gonzalez, H., C. Hagerling, \& Z. Werb. 2018. Roles of the immune system in cancer: from tumor initiation to metastatic progression. Genes Dev. 32:1267-1284. https://doi. org/10.1101/gad.314617.118

Goto, T., M. M. R. Sarker, M. Zhong, S. Tanaka, \& E. Gohda. 2010. Enhancement of immunoglobulin $m$ production in $B$ cells by the extract of red bell pepper. J. Health Sci. 56:304309. https://doi.org/10.1248/jhs.56.304

Hanusova, E., C. Hrncar, A. Hanus, \& M. Oracova. 2015. Effect of breed on some parameters of egg quality in laying hens. Acta Fytotechn. Zootechn. 18:20-24. https://doi. org/10.15414/afz.2015.18.01.12-24

Hernandez-Campoz, F. J., E. B. Fuente, \& B. TorrestianaSanchez. 2010. Purification of egg yolk immunoglobulin (igy) by ultrafiltration: effect of ph, ionic strength, and membrane properties. J. Agric. Food Chem. 58:187-193. https://doi.org/10.1021/jf902964s

Hidayat, C. \& S. A. Asmarasari. 2015. Native chicken production in Indonesia: A review. J. Peternak. Indones. 17:1-11. https://doi.org/10.25077/jpi.17.1.1-11.2015

Hua, Z. \& B. Hou. 2013. TLR signaling in b-cell development and activation. Cell Mol. Immunol. 10:103-106. https://doi. org $/ 10.1038 / \mathrm{cmi} .2012 .61$

Iwasaki, A. \& R. Medzhitov. 2004. Toll-like receptor control of the adaptive immune responses. Nat. Immunol. 5:987-995. https://doi.org/10.1038/ni1112

Jajere, S. M., L. Hassan, S. A. Aziz, Z. Zakaria, J. Abu, F. Nordin, \& N. M. Faiz. 2019. Salmonella in native 'village' chickens (Gallus domesticus): prevalence and risk factors from farms in south-central peninsular Malaysia. Poult. Sci. J. 98:59615970. https://doi.org/10.3382/ps/pez392

Jones, D. R. 2012. Haugh Unit: Gold Standard of Egg Quality. National Egg Quality School. Indianapolis 7:47-51

Ko, K. Y. \& D. U. Ahn. 2007. Preparation of immunoglobulin Y from egg yolk using ammonium sulfate precipitation and ion exchange chromatography. Poult. Sci. J. 86:400-407. https://doi.org/10.1093/ps/86.2.400

Kumalasari, I. D., E. Harmayani, L. A. Lestari, S. Raharjo, W. Asmara, K. Nishi, \& T. Sugahara. 2012. Evaluation of immunostimulatory effect of the arrowroot (Maranta arundinacea. 1) in vitro and in vivo. Cytotechnology 64:131-137. https://doi.org/10.1007/s10616-011-9403-4

Lee, W. Y., R. Lee, H. C. Kim, K. H. Lee, K. S. Noh, H. W. Kim, \& J. H. Kim. 2013. Consumption of water-soluble egg yolk extract on growth rate, changes in blood cholesterol levels, and immune modulation in BALB/c mice. Korean J. Food Sci. An. 33:587-594. https://doi.org/10.5851/ kosfa.2013.33.5.587

Lordelo, M., E. Fernandes, R. J.B. Bessa, \& S. P. Alves. 2017. Quality of eggs from different laying hen production systems, from indigenous breeds and specialty eggs. Poult. Sci. 96:1485-1491. https://doi.org/10.3382/ps/pew409

Lordelo, M., J. Cid, C. M.D.S. Cordovil, S. P. Alves, Rui J.B. Bessa, \& I. Carolino. 2019. A comparison between the quality of eggs from indigenous chicken breeds and that from commercial layers. Poult. Sci. J. 99:1768-1776. https:// doi.org/10.1016/j.psj.2019.11.023

Marshall, J. S., R. Warrington, W. Watson, \& H. L. Kim. 2018. An introduction to immunology and immunopathology. Allergy Asthma Clin. Immunol. 14:1-14. https://doi. org/10.1186/s13223-018-0278-1

Meram, C. \& J. Wu. 2017. Anti-Inflammatory effects of egg yolk livetins ( $\alpha, \beta$, and $\gamma$-livetin) fraction and its enzymatic hydrolysates in lipopolysaccharide-induced raw 264.7 macrophages. Food Res. Int. 100:449-59. https://doi. org/10.1016/j.foodres.2017.07.032

Messay, B., A. Lim, \& A. L. Marshland. 2012. Current understanding of the bi-directional relationship of major depression with inflammation. Biol. Mood Anxiety Disord. 2:1-4. https://doi.org/10.1186/PREACCEPT-1461493759628561

Miranda, J. M., X. Anton, C. Redondo-Valbuena, P. RocaSaavedra, J. A. Rodriguez, A. Lamas, C. M. Franco, \& A. Cepeda. 2015. Egg and egg-derived foods: effects on human health and use as functional foods. Nutrients 7:706729. https://doi.org/10.3390/nu7010706

Muladno. 2008. Local Chicken Genetic Resources and Production Systems in Indonesia. Prepared by Muladno Muladno. GCP/RAS/228/GER Working paper no. 6 Rome.

Nieman, D. C. \& L. M. Wentz. 2019. The compelling link between physical activity and the body's defense system. J. Sport Health Sci. 8:201-217. https://doi.org/10.1016/j. jshs.2018.09.009

Nishimoto, S., A. Muranaka, K. Nishi, A. Kadota, \& T. Sugahara. 2012. Immunomodulatory effects of citrus auraptene in vitro and in vivo. J. Funct. Foods 4:883-890. https://doi.org/10.1016/j.jff.2012.06.005

Noh, E. Mi, J. M. Kim, H. Y. Lee, H. K. Song, S. O. Joung, H. J. Yang, M. J. Kim, K. S. Kim, \& Y. R. Lee. 2019. Immunoenhancement effects of platycodon grandiflorum extracts in splenocytes and a cyclophosphamide-induced immunosuppressed rat model. BMC Complementary and Alternative Medicine 19:322. https://doi.org/10.1186/ s12906-019-2724-0

Rehman, S. A., S. Akhter, S. H. Khan, M. \& A. Anjum. 2016. A comparative study on quality, proximate composition and cholesterol content of eggs and meat in fayoumi and commercial white leghorn chickens. Cogent Food Agric. 2:1195539. https://doi.org/10.1080/23311932.2016.1195539

Ruprecht, C. R. \& A. Lanzavecchia. 2006. Toll-like receptor stimulation as a third signal required for activation of human naive b cells. Eur. J. Immunol. 36:810-816. https://doi. org/10.1002/eji.200535744

Sarker, Md M. R. \& E. Gohda. 2013. Promotion of anti-keyhole limpet hemocyanin igm and igg antibody productions in 
vitro by red bell pepper extract. J. Funct. Foods. 5:19181926. https://doi.org/10.1016/j.jff.2013.09.013

Shi, S. R., K. H. Wang, T. C. Dou, \& H. M. Yang. 2009. Egg weight affects some quality traits of chicken eggs. J. Food Agric and Environ 7:432-434

Sokolowicz, Z., J. Krawczyk, \& M. Dykiel. 2018. Effect of alternative housing system and hen genotype on egg quality characteristics. Emir. J. Food Agric. 30:695-703. https://doi. org/10.9755/ejfa.2018.v30.i8.1753

Su, Y., Y. Tian, R. Yan, C. Wang, F. Niu, \& Y. Yang. 2015. Study on a novel process for the separation of phospholipid, tryacylglycerol, and cholesterol from egg yolk. J. Food Sci. Technol 52:4856-4592. https://doi.org/10.1007/ s13197-014-1513-5

Sugahara, T., F. Murakami, Y. Yamada, \& T. Sasaki. 2000. The mode of actions of lysozyme as an immunoglobulin production stimulating factor. Biochim. Biophys. Acta General Subj. 1475:27-34. https://doi.org/10.1016/ S0304-4165(00)00041-6

Tagashira, A., K. Nishi, S. Matsumoto, \& T. Sugahara. 2018. Anti-inflammatory effect of lysozyme from hen egg white on mouse peritoneal macrophages. Cytotechnology 70:929-38. https://doi.org/10.1007/s10616-017-0184-2

Ulupi, N., Muladno, C. Sumantri, \& I. W.T. Wibawan. 2014. Study of kampung chicken resistance against salmonella enteritidis using tlr4 gene as marker. Int. J. Poul. Sci. 13:467-71. https://doi.org/10.3923/ijps.2014.467.472

Ulupi, N., Muladno, C. Sumantri, \& I. W. T. Wibawan. 2013. Association of TLR4 gene genotype and resistance against Salmonella enteritidis natural infection in kampung chicken. Int. J. Poult. Sci. 12:445-50. https://doi.org/10.3923/ ijps.2013.445.450

USDA-Agricultural Marketing Service. 2000. The Egg Grading Manual. Agricultural Handbook 75:17.

Veldhoen, M., \& V. Brucklacher-Waldert. 2012. Dietary Influences on intestinal immunity. Nature Reviews Immunology 12:696-708. https://doi.org/10.1038/nri3299

Wambui, C. C., E. K. Njoroge, \& C. B. Wasike. 2018. Characterisation of physical egg qualities in indigenous chicken under free range system of production in western kenya. Livest. Res. Rural. Dev. 30 (7).

Wei, L. J., Abbas F.M. Alkarkhi, \& N. Huda. 2019. Physicochemical properties of egg yolk powder from eggs of different types of bird. Int. J. Adv. Sci. Eng. Inf. Technol. 9:373-78. https://doi.org/10.18517/ijaseit.9.1.3046

Wulandari, Z., D. Fardiaz, C. Budiman, T. Suryati, \& D. Herawati. 2015. Purification of egg white lysozyme from Indonesian kampung chicken and ducks. Med. Pet. 38: 18 26. https://doi.org/10.5398/medpet.2015.38.1.18 